JURNAL RESPIRASI

JR

Vol. 3 No. 1 Januari 2017

\title{
Penanganan Tuberkulosis Resistan Obat pada Daerah Terpencil: Mission Impossible?
}

\author{
Ivan Banjuradja, ${ }^{1}$ Asep Purnama ${ }^{2}$ \\ ${ }^{1}$ Dokter PTT RSUD dr. T.C. Hillers, Kabupaten Sikka, Nusa Tenggara Timur \\ ${ }^{2}$ SMF Ilmu Penyakit Dalam RSUD dr. T.C. Hillers, Kabupaten Sikka, Nusa Tenggara Timur
}

\begin{abstract}
Background: Complicated drug-resistant Tuberculosis (TB) management becomes a distinctive challenge for health care provider in rural area. Case: We reported 6 drug-resistant TB cases that were found in Sikka Regency, East Nusa Tenggara, based on rapid molecular test. Each case had unique problem which needs specific management, such as difference between the conventional and rapid drug susceptibility test, appearance of second line injection drug resistant (Pre-XDR TB), Human Immunodeficiency Virus (HIV) co-infection, emergence of serious acute psychosis side effect, and the drop out management. Discussion: We will discuss the management of each individual's problem that arises during the antitubercular treatment monitoring and the requiring regimen modification under the national guideline. Conclusion: Drug-resistant TB management is a very complex matter. However, with sustainable effort, commitment, and collaboration between referral center and health care provider in rural area, guidelin be appropriate management could be achieved. Despite its possibility, prevention of resistant TB should have been done as early as possible, one of them is completion of regular TB treatment.
\end{abstract}

Key words: Drug resistant Tuberculosis, rural area, regimen modification

Correspondence: Ivan Banjuradja, RSUD dr. T.C. Hillers, J1 Wairklau, No. 1, 86113, Kota Baru, Alok Tim., Kabupaten Sikka, Nusa Tenggara Timur. Email: jurnal.respirasi@gmail.com

\section{PENDAHULUAN}

Tuberkulosis (TB) resistan obat adalah keadaan dimana kuman Mycobacterium tuberculosis (M. tuberculosis) sudah tidak dapat lagi dibunuh dengan obat anti TB (OAT). Pada tahun 2013 WHO memperkirakan terdapat 6.800 kasus baru TB Multi Drug Resistant (MDR) di Indonesia setiap tahunnya, di mana $2 \%$ merupakan kasus baru dan $12 \%$ merupakan kasus pengobatan ulang. ${ }^{1} \mathrm{~TB}$ resistan obat adalah fenomena buatan manusia dimana penatalaksanaannya lebih rumit dan memerlukan lebih banyak perhatian daripada TB yang tidak resistan (TB reguler). Salah satu kerumitan pada penatalaksanaan TB resistan obat adalah jumlah dan jenis obat yang lebih banyak dan beragam serta waktu pengobatan yang lebih lama. ${ }^{2}$ Konsumsi OAT yang banyak dan beragam tentu berpotensi menimbulkan efek samping yang banyak dan beragam pula. ${ }^{3}$ Menangani kerumitan TB resistan obat merupakan tantangan tersendiri pada layanan kesehatan di daerah terpencil dengan sumber daya terbatas. Pada laporan seri kasus ini akan dilaporkan penanganan 6 kasus TB resistan obat di RSUD dr. T.C. Hillers Maumere, Kabupaten Sikka, Nusa Tenggara Timur.

\section{KASUS}

Karakteristik keenam pasien TB resistan obat dapat dilihat pada tabel 1 .

\section{DISKUSI}

Pengelolaan TB resistan obat yang penuh kerumitan, seperti jangka waktu pengobatan yang panjang, jumlah dan jenis obat yang beragam, serta kemungkinan timbulnya berbagai efek samping menjadi tantangan tersendiri pada daerah terpencil. Adapun alur diagnosis TB resistan obat dapat dilihat pada gambar 1 . 
Tabel 1. Karakteristik pasien-pasien TB resistan obat

\begin{tabular}{|c|c|c|c|c|c|c|}
\hline & Pasien 1 & Pasien 2 & Pasien 3 & Pasien 4 & Pasien 5 & Pasien 6 \\
\hline Jenis kelamin & Laki-laki & Perempuan & Perempuan & Perempuan & Perempuan & Laki-laki \\
\hline Usia & 58 tahun & 62 tahun & 42 tahun & 32 tahun & 45 tahun & 23 tahun \\
\hline \multicolumn{7}{|l|}{ Gejala } \\
\hline - Batuk & + & + & + & + & + & + \\
\hline - Hemoptisis & + & - & - & - & + & - \\
\hline - Sesak nafas & + & + & + & + & + & + \\
\hline - Penurunan BB & + & + & + & + & + & + \\
\hline $\begin{array}{l}\text { - Keringat } \\
\text { malam }\end{array}$ & + & + & - & + & - & - \\
\hline - Demam & - & + & + & - & + & + \\
\hline - Lemah & + & + & + & - & + & + \\
\hline - BB awal & $40 \mathrm{~kg}$ & $33 \mathrm{~kg}$ & $30 \mathrm{~kg}$ & $32 \mathrm{~kg}$ & $35 \mathrm{~kg}$ & $40 \mathrm{~kg}$ \\
\hline $\begin{array}{l}\text { Faktor risiko } \\
\text { MDR }\end{array}$ & After default & Kasus relaps & After default & Gagal terapi & After default & $\begin{array}{c}\text { Koinfeksi TB- } \\
\text { HIV }\end{array}$ \\
\hline Hasil TCM & $\begin{array}{l}\text { MTB detected } \\
\text { high } \\
\text { Rif resistance } \\
\text { detected }\end{array}$ & $\begin{array}{l}\text { MTB detected } \\
\text { high } \\
\text { Rif resistance } \\
\text { detected }\end{array}$ & $\begin{array}{l}\text { MTB detected } \\
\text { high } \\
\text { Rif resistance } \\
\text { detected }\end{array}$ & $\begin{array}{l}\text { MTB detected } \\
\text { low } \\
\text { Rif resistance } \\
\text { detected }\end{array}$ & $\begin{array}{l}\text { MTB detected } \\
\text { low } \\
\text { Rif resistance } \\
\text { detected }\end{array}$ & $\begin{array}{l}\text { MTB detected } \\
\text { low } \\
\text { Rif resistance } \\
\text { detected }\end{array}$ \\
\hline Resistensi OAT & Tidak resisten & H,R,E,S,Km,Amk & $\mathrm{H}, \mathrm{R}$ & $\mathrm{H}, \mathrm{R}$ & Belum ada hasil & Belum ada hasil \\
\hline Status HIV & Non reaktif & Non reaktif & Non reaktif & Non reaktif & Non reaktif & Reaktif \\
\hline $\begin{array}{l}\text { Regimen terapi } \\
\text { awal }\end{array}$ & $\begin{array}{c}\text { Km-Eto-Lfx -Cs- } \\
\text { Z-E+B6 }\end{array}$ & $\begin{array}{c}\text { Km-Eto-Lfx-Cs- } \\
\text { Z-E +B6 }\end{array}$ & $\begin{array}{c}\text { Km-Eto-Lfx-Cs- } \\
\text { Z-E+B6 }\end{array}$ & $\begin{array}{c}\text { Km-Eto-Lfx-Cs- } \\
\text { Z-E+B6 }\end{array}$ & $\begin{array}{c}\text { Km-Eto-Lfx -Cs- } \\
\text { Z-E+B6 }\end{array}$ & $\begin{array}{c}\text { Km-Eto-Lfx-Cs- } \\
\text { Z-E+B6 }\end{array}$ \\
\hline Tablet/hari & 13 tablet & $11 \frac{1}{2}$ tablet & $11 \frac{1}{2}$ tablet & $11 \frac{1}{2}$ tablet & $12 \frac{1}{2}$ tablet & 13 tablet \\
\hline Efek samping & $\begin{array}{c}\text { Athralgia, } \\
\text { hiperurisemia }\end{array}$ & $\begin{array}{c}\text { Gangguan GI, } \\
\text { lemah }\end{array}$ & $\begin{array}{l}\text { Gangguan GI, } \\
\text { Psikosis akut }\end{array}$ & $\begin{array}{l}\text { Gangguan GI, } \\
\text { insomnia }\end{array}$ & Gangguan GI & Gangguan GI \\
\hline $\begin{array}{l}\text { Modifikasi } \\
\text { regimen }\end{array}$ & $\begin{array}{c}\text { Km-Eto-Lfx -Cs- } \\
\text { Z-E-B6 } \\
\text { +OAINS, } \\
\text { allopurinol }\end{array}$ & $\begin{array}{c}\text { Cm-Eto-Lfx-Cs- } \\
\text { Z-B6 } \\
\text { +antiemetik }\end{array}$ & $\begin{array}{l}\text { Km-Eto-Lfx- } \\
\text { PAS-Z-E-2(B6) } \\
\text { +antiemetik, } \\
\text { antipsikotik }\end{array}$ & $\begin{array}{c}\text { Km-Eto-Lfx-Cs- } \\
\text { Z-E-B6 } \\
\text { +antiemetik }\end{array}$ & $\begin{array}{c}\text { Km-Eto-Lfx-Cs- } \\
\text { Z-E-B6 }\end{array}$ & $\begin{array}{c}\text { Km-Eto-Lfx-Cs- } \\
\text { Z-E-B6 } \\
\text { +antiemetik }\end{array}$ \\
\hline $\begin{array}{l}\text { Keadaan } \\
\text { terakhir }\end{array}$ & $\begin{array}{l}\text { Pengobatan } \\
\text { tahap lanjut }\end{array}$ & $\begin{array}{l}\text { Drop out pada } \\
\text { bulan ke } 9 \\
\text { pengobatan }\end{array}$ & $\begin{array}{l}\text { Pengobatan } \\
\text { tahap awal }\end{array}$ & $\begin{array}{l}\text { Pengobatan } \\
\text { tahap awal }\end{array}$ & $\begin{array}{c}\text { Drop out pada } \\
\text { bulan pertama } \\
\text { pengobatan }\end{array}$ & $\begin{array}{c}\text { Pengobatan } \\
\text { tahap awal }\end{array}$ \\
\hline
\end{tabular}

BB: berat badan; TCM: Tes cepat molekuler; Km: Kanamisin; Eto: Etionamid; Lfx: Levofloksasin; Cs: Sikloserin; Z: Pirazinamid; E: Etambutol; B6: vitamin B6 (piridoksin); GI: gastrointestinal

Seri kasus yang ditampilkan merupakan seluruh kasus TB resistan obat yang ditemukan di Kabupaten Sikka sejak tersedianya fasilitas Tes Cepat Molekuler (TCM) pada Januari 2016.

\section{Karakteristik dan gejala}

Karakteristik usia pasien beragam. Dari total keseluruhan kasus, terdapat 2 pasien laki-laki dan 4 perempuan. Berdasarkan data memperlihatkan bahwa laki-laki lebih berisiko terhadap TB reguler dibandingkan perempuan. Akan tetapi pada kasus TB resistan obat, perempuan memiliki risiko yang lebih tinggi dibandingkan laki-laki. Alasan peningkatan risiko TB resistan obat terhadap perempuan belum jelas dan memerlukan investigasi lebih lanjut. ${ }^{4,5}$
Keluhan batuk lebih dari 3 minggu, sesak nafas berhubungan dengan aktivitas, dan penurunan berat badan merupakan gejala TB yang dialami oleh seluruh pasien. Selain itu rasa lemah (5 dari 6) dan demam (4 dari 6) merupakan gejala yang dialami oleh sebagian besar pasien. Sebuah studi epidemiologi mengenai TB MDR menyatakan gejala batuk berdahak $(95.1 \%)$ dan penurunan berat badan $(91,4 \%)$ merupakan gejala yang paling umum pada pasien TB MDR. ${ }^{6}$

\section{Kriteria terduga TB resistan obat}

Tiga dari enam pasien (pasien 1, 3, dan 5) dicurigai terinfeksi TB resistan obat karena memiliki riwayat lalai berobat (after default). Riwayat pengobatan OAT yang tidak adekuat merupakan salah satu faktor risiko yang telah banyak diketahui terhadap munculnya TB resistan obat. ${ }^{7,8}$ 


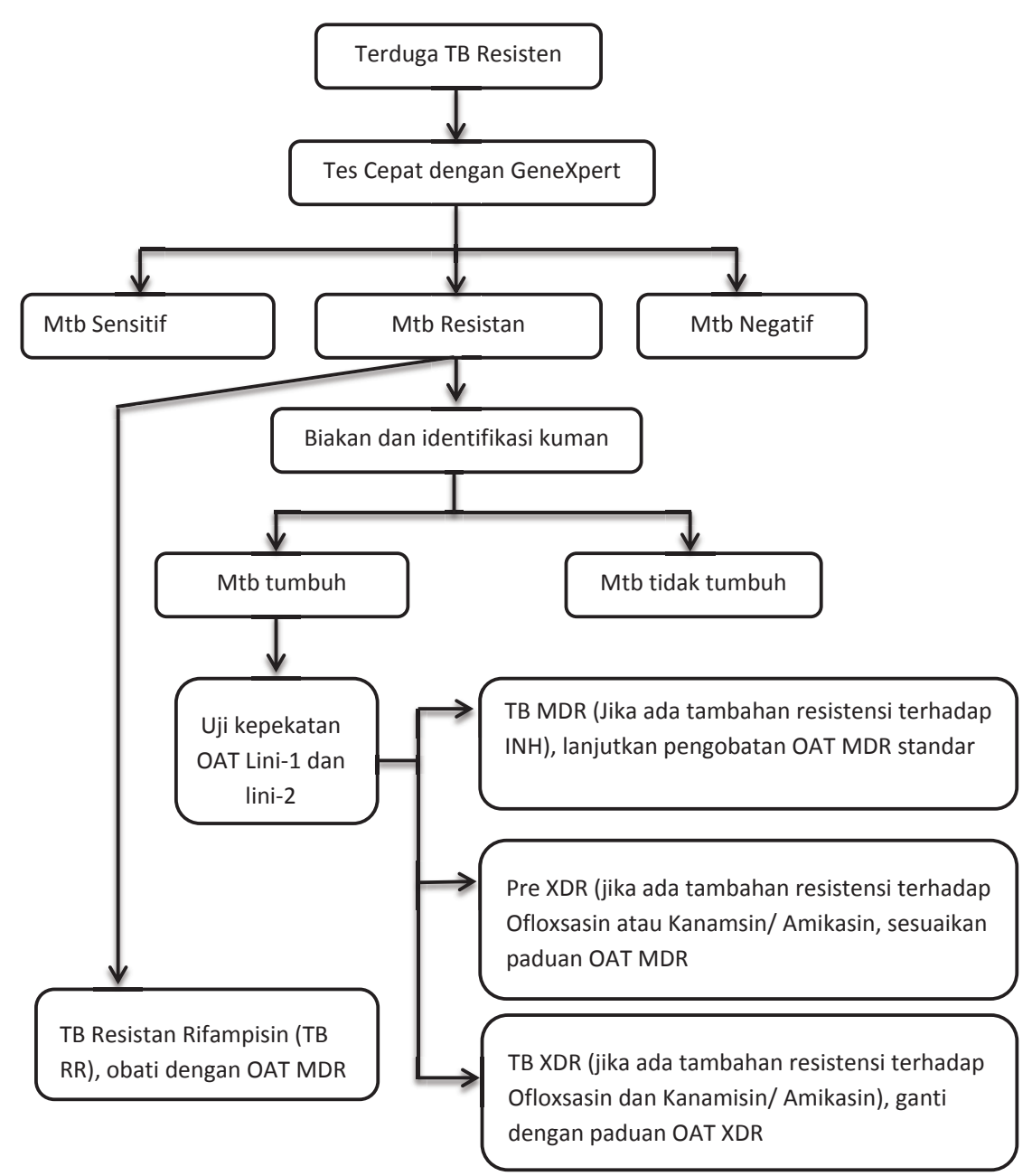

Gambar 1. Alur diagnosis TB resistan obat ${ }^{1}$

Walaupun kuman TB resistan obat dapat ditransmisikan secara langsung antar individu (resistensi primer), kebanyakan kasus TB resistan obat muncul setelah riwayat pengobatan yang tidak adekuat sehingga memungkinkan strain $M$. tuberculosis yang resistan menjadi dominan. ${ }^{9}$

Dua pasien (pasien 2 dan 4) dicurigai terinfeksi TB resistan obat karena mengalami kegagalan pada tahap pengobatan. Pasien 2 mengalami gejala khas TB setelah menerima pengobatan OAT kategori 2 lengkap sebelumnya. Pada tahun 2011 pasien ini pertama kali terdiagnosis TB dan menerima pengobatan OAT kategori 1 selama 6 bulan sebelum dinyatakan gagal, dan dilanjutkan pemberian OAT kategori 2 selama 8 bulan pada tahun 2012. Pasien 4 gagal mengalami konversi sputum BTA setelah 6 bulan pengobatan TB dengan OAT kategori 1 pada tahun 2016. Berkaca dari riwayat pengobatan kedua pasien di atas (pasien 2 dan 4), dapat dilihat bahwa seharusnya pemeriksaan uji kepekaan dilakukan lebih awal sebelum memulai pemberian OAT kategori 2. Sesuai pedoman bahwa semua pasien TB yang mempunyai riwayat pengobatan TB sebelumnya (baik gagal kategori 1 atau 2), harus diperiksa dengan TCM terlebih dahulu sebelum memulai pengobatan TB kategori $2 .{ }^{1}$ Sayangnya TCM belum tersedia di Kabupaten Sikka pada tahun 2011.

Pasien 6 diduga terinfeksi TB resistan karena tidak memberikan respons perbaikan klinis pasca 1 bulan pengobatan OAT kategori 1 dan memiliki koinfeksi HIV. Beberapa mekanisme biologis menghubungkan TB resistan obat dengan infeksi HIV. Pasien HIV malabsorbsi obat, khususnya Rifampisin dan Etambutol dapat mengalami resisten obat karena dosis obat yang sub optimal. Penurunan daya tahan pada infeksi HIV juga diduga menyebabkan progresivitas strain kuman M. tuberculosis resistan obat yang diketahui kurang virulen. ${ }^{10}$ Namun sampai saat ini belum ada hubungan signifikan antara infeksi HIV sebagai faktor risiko munculnya TB resistan obat. ${ }^{7,10}$

Selain 4 kriteria yang sudah disebutkan di atas terdapat 5 kriteria lain yang membuat seseorang dengan gejala TB dicurigai terinfeksi TB resistan obat, yaitu:

1. Pasien TB gagal pengobatan kategori 2

2. Pasien TB pengobatan kategori 2 tidak konversi

3. Pasien TB yang mempunyai riwayat pengobatan TB tidak standar serta menggunakan kuinolon dan obat injeksi lini kedua minimal selama 1 bulan 
4. Pasien TB pengobatan kategori 1 yang tidak konversi

5. Terduga TB yang mempunyai riwayat kontak erat dengan pasien TB MDR. ${ }^{1}$

\section{Regimen, dosis, dan lama pemberian paduan OAT}

Hasil pemeriksaan TCM seluruh dahak pasien mengandung kuman $M$. tuberculosis yang resistan Rifampisin. Tes cepat molekuler adalah salah satu metode tes cepat yang dapat mendeteksi mutasi genom yang berhubungan dengan resistensi Rifampisin pada kuman TB dalam waktu kurang dari 2 jam. Pemeriksaan ini dianjurkan sebagai tes diagnosis inisial pada pasien dewasa dan anakanak yang dicurigai menderita TB MDR. ${ }^{11}$ Seluruh pasien terduga TB resistan obat menjalani pemeriksaan TCM, sedangkan pasien dengan hasil MTB rifampicin resistant melanjutkan dengan pemeriksaan biakan. ${ }^{1}$ Oleh karena Kabupaten Sikka belum mampu melakukan pemeriksaan kultur dan uji kepekaan, maka spesimen dahak dikirim ke laboratorium rujukan di Surabaya.

Setelah didapatkan hasil pemeriksaan TCM, sambil menunggu hasil pemeriksaan biakan dan uji kepekaan, seluruh pasien diobati dengan paduan OAT standar TB MDR yang terdiri dari injeksi Kanamisin (Km), Etionamid (Eto), Levofloksasin (Lfx), Sikloserin (Cs), Pirazinamid (Z), dan Etambutol (E). ${ }^{1}$ Masing-masing diberikan dengan dosis menurut berat badan sesuai pedoman Kementerian Kesehatan (tabel 2).

Paduan OAT TB resistan obat saat ini adalah paduan standar yang pada permulaan pengobatan akan diberikan sama kepada semua pasien TB resistan rifampisin atau TB MDR. Paduan standar yang diberikan adalah $\mathrm{Km}$ - Eto - Lfx - Cs $-\mathrm{Z}-(\mathrm{E}) /$ Eto $-\mathrm{Lfx}-\mathrm{Cs}-\mathrm{Z}-(\mathrm{E})$. Dalam pemantauan selanjutnya paduan standar ini akan disesuaikan, baik jenis obat maupun dosisnya sesuai dengan hasil pemeriksaan uji kepekaan terhadap OAT lainnya, timbulnya efek samping yang berat, dan perubahan berat badan. Pengobatan dibagi menjadi 2 tahap, yaitu tahap awal dan tahap lanjutan. Tahap awal adalah tahap pengobatan dengan menggunakan obat oral dan obat suntikan (Kanamisin atau Kapreomisin) yang diberikan sekurang-kurangnya selama 6 bulan atau 4 bulan setelah terjadi konversi biakan. Tahap lanjutan adalah tahap pengobatan setelah selesai pengobatan tahap awal dan pemberian suntikan dihentikan. Lama pengobatan tahap awal dan tahap lanjutan minimal 18 bulan setelah terjadi konversi biakan. ${ }^{1}$

Selain OAT pada seluruh pasien juga diberikan vitamin B6 (piridoksin) dengan dosis $100 \mathrm{mg} / \mathrm{hari}$. Sesuai pedoman piridoksin ditambahkan pada pasien yang mendapat sikloserin dengan dosis $50 \mathrm{mg}$ untuk setiap $250 \mathrm{mg}$ sikloserin. ${ }^{1}$ Sikloserin termasuk OAT bakteriostatik lini kedua yang telah lama diketahui memiliki efek samping yang terkait gangguan sistem saraf pusat melalui aktivitasnya sebagai antagonis piridoksin dan meningkatkan ekskresi piridoksin. Oleh karena itu, suplementasi piridoksin direkomendasikan untuk mencegah efek samping tersebut. ${ }^{12}$

\section{Hasil uji kepekaan dan modifikasi regimen}

Berdasarkan hasil pemeriksaan biakan dan uji kepekaan OAT, pasien 1 memiliki hasil sensitif terhadap seluruh OAT lini 1, Kanamisin, dan Ofloksasin. Hal ini tidak sesuai dengan pemeriksaan TCM (rifampicin resistant). Saat hasil pemeriksaan kepekaan keluar, pasien sudah mengonsumsi paduan OAT TB MDR selama 2 bulan. Pengobatan pada pasien 1 tetap dilanjutkan tanpa mengubah regimen pengobatan, dan pemantauan dilanjutkan sesuai pedoman Uji kepekaan tidak bertujuan untuk mengonfirmasi hasil pemeriksaan TCM, melainkan untuk mengetahui pola resistensi kuman TB lainnya. Jika terdapat perbedaan hasil antara pemeriksaan TCM dengan hasil pemeriksaan uji kepekaan, maka hasil pemeriksaan resisten rifampisin atau MDR menjadi dasar penegakan diagnosis. ${ }^{1}$

Pasien 2 memiliki hasil uji kepekaan OAT yang positif resisten terhadap Isoniazid, Rifampisin, Streptomisin, Kanamisin, Etambutol, dan Amikasin. Berdasarkan hasil uji kepekaan ini, pasien 2 ditetapkan sebagai TB pre-XDR, yaitu TB yang memiliki resistensi terhadap isoniazid dan rifampisin serta salah satu dari golongan florokuinolon atau OAT injeksi lini kedua (Kanamisin, Amikasin, Kapreomisin) tapi tidak keduanya. Jika terdapat resistensi pada kedua golongan florokuinolon dan OAT injeksi lini kedua, maka disebut sebagai TB XDR. Riwayat

Tabel 2. Perhitungan dosis OAT MDR ${ }^{1}$

\begin{tabular}{|c|c|c|c|c|}
\hline \multirow{2}{*}{ OAT } & \multicolumn{4}{|c|}{ Berat Badan (BB) } \\
\hline & $<33 \mathrm{~kg}$ & $33-50 \mathrm{~kg}$ & $51-70 \mathrm{~kg}$ & $>70 \mathrm{~kg}$ \\
\hline Pirazinamid & $20-30 \mathrm{mg} / \mathrm{kg} / \mathrm{hari}$ & $750-1500 \mathrm{mg}$ & $1500-1750 \mathrm{mg}$ & $1750-2000 \mathrm{mg}$ \\
\hline Kanamisin & 15-20 mg/kg/hari & $500-750 \mathrm{mg}$ & $1000 \mathrm{mg}$ & $1000 \mathrm{mg}$ \\
\hline Etambutol & 20-30 mg/kg/hari & $800-1200 \mathrm{mg}$ & $1200-1600 \mathrm{mg}$ & $1600-2000 \mathrm{mg}$ \\
\hline Kapreomisin & $15-20 \mathrm{mg} / \mathrm{kg} / \mathrm{hari}$ & $500-750 \mathrm{mg}$ & $1000 \mathrm{mg}$ & $1000 \mathrm{mg}$ \\
\hline Levofloksasin & $7,5-10 \mathrm{mg} / \mathrm{kg} / \mathrm{hari}$ & $750 \mathrm{mg}$ & $750 \mathrm{mg}$ & $750-1000 \mathrm{mg}$ \\
\hline Moksifloksasin & 7,5-10 mg/kg/hari & $400 \mathrm{mg}$ & $400 \mathrm{mg}$ & $400 \mathrm{mg}$ \\
\hline Sikloserin & $15-20 \mathrm{mg} / \mathrm{kg} / \mathrm{hari}$ & $500 \mathrm{mg}$ & $750 \mathrm{mg}$ & $750-1000 \mathrm{mg}$ \\
\hline Etionamid & 15-20 mg/kg/hari & $500 \mathrm{mg}$ & $750 \mathrm{mg}$ & $750-1000 \mathrm{mg}$ \\
\hline PAS & $150 \mathrm{mg} / \mathrm{kg} / \mathrm{hari}$ & $8 \mathrm{~g}$ & $8 \mathrm{~g}$ & $8 \mathrm{~g}$ \\
\hline
\end{tabular}


pajanan terhadap antibiotik golongan florokuinolon dan aminoglikosida sebagai pengobatan infeksi bakteri selain TB diperkirakan menimbulkan evolusi resistensi terhadap obat ini. ${ }^{13}$

Proses penanganan selanjutnya adalah melakukan perubahan regimen standar OAT meliputi injeksi Kanamisin dengan Kapreomisin serta menghentikan pemberian Etambutol. Hal ini sesuai dengan pedoman bahwa apabila terbukti terdapat resistensi terhadap Kanamisin, maka Kapreomisin dianjurkan sebagai OAT injeksi lini kedua. ${ }^{1,11}$ Etambutol tidak diberikan jika terbukti sudah resisten.

Pasien 3 dan 4 memiliki hasil tes kepekaan OAT yang resisten terhadap isoniazid dan rifampisin. Pasien didiagnosis sebagai TB MDR. Tidak ada perubahan pada regimen paduan OAT yang diberikan.

\section{Efek samping dan penanganannya}

Data dari seluruh kasus memperlihatkan bahwa efek samping yang paling banyak terjadi pasca pemberian paduan OAT adalah gangguan gastrointestinal seperti mual, muntah, dan rasa tidak nyaman pada ulu hati terutama pada minggu-minggu awal pengobatan. Seluruh pasien dianjurkan untuk menelan OAT pada malam hari, sedangkan pada pasien 2, 3, 4, dan 6 diberikan obat tambahan berupa antiemetik ondansetron $4 \mathrm{mg}$ yang dikonsumsi 30 menit sebelum menelan OAT. Gangguan gastrointestinal seperti mual/muntah merupakan efek samping yang paling sering ditemukan akibat pemberian OAT TB resistan obat, yakni dengan prevalensi 32.8\%. Efek samping mual muntah terutama terdapat pada OAT etionamid, PAS, etambutol, dan pirazinamid. Berdasarkan literatur, penanganan efek samping ini dapat dilakukan dengan cara menganjurkan pasien untuk menelan obat pada malam hari atau pemberian antiemetik seperti metoclopramide atau ondansetron sebelum menelan OAT. Perhatian khusus dalam penanganan keluhan sakit ulu hati, pada pasien yang mengkonsumsi paduan OAT, antasida tidak dianjurkan karena dapat menghambat absorbsi kuinolon. ${ }^{11}$

Pasien 1 mengalami efek samping lain berupa atralgia dan peningkatan kadar asam urat hingga $11.9 \mathrm{mg} / \mathrm{dL}$. Guna mengatasi efek samping tersebut maka ditambahkan ibuprofen 3x400mg dan allopurinol $1 \times 300 \mathrm{mg}$. Menurut literatur, athralgia merupakan efek samping pemberian OAT TB resistan obat yang cukup sering dengan prevalensi $16.4 \%$. Obat anti TB yang diketahui berhubungan dengan efek samping atralgia dan peningkatan kadar asam urat antara lain adalah pirazinamid dan florokuinolon (levofloksasin). Efek samping ini dapat diatasi dengan pemberian OAINS (indometasin atau ibuprofen). ${ }^{11}$ Sedangkan pada peningkatan asam urat dapat diberikan alopurinol. ${ }^{1}$

Pasien 3 mengalami efek samping gangguan psikosis akut berupa halusinasi visual dan waham setelah 3 bulan pemberian paduan standar OAT. Untuk menilai apakah efek samping tersebut memang disebabkan oleh penggunaan obat, digunakan perhitungan skor naranjo. Skor Naranjo pasien terhadap efek samping sikloserin menunjukkan skor 4 yang berarti bahwa sikloserin mungkin merupakan penyebab timbulnya kelainan pada pasien. ${ }^{14}$ Pasien kemudian didiagnosis sebagai gangguan psikosis akut yang diinduksi oleh sikloserin.

Sikloserin dapat menyebabkan gangguan psikiatri melalui aktivitasnya yang memengaruhi neurotransmiter GABA transferase. ${ }^{15}$ Selain itu Sikloserin juga memengaruhi transmisi glutamatergik melalui aktivitas nya pada AMPN Kainase dan reseptor NMDA. ${ }^{16}$ Prevalensi gangguan psikosis akibat OAT TB MDR sendiri sebesar 3,4\%. ${ }^{11}$ Sikloserin memiliki efek samping psikiatri dan sistem saraf pusat lebih tinggi daripada obat lini kedua lainnya. ${ }^{17}$

Penggunaan sikloserin akhirnya dihentikan sementara OAT lain masih dilanjutkan. Bersamaan dengan penghentian sikloserin, Haloperidol $2 \times 5 \mathrm{mg}$ diberikan pada pasien untuk mengatasi gejala psikosis. Hal ini sesuai dengan literatur dimana apabila terjadi gejala psikosis, sikloserin harus dihentikan selama 1-4 minggu, dan obat antipsikotik harus diberikan sampai gejala psikosis terkontrol. Pada kasus dosis piridoksin (vitamin B6) ditingkatkan dari $100 \mathrm{mg} /$ hari menjadi $200 \mathrm{mg} /$ hari sesuai pedoman. ${ }^{1,11}$

Gejala psikosis pada pasien berkurang pada hari ketiga dan menghilang pada hari kesepuluh pasca penghentian Sikloserin. Sikloserin tidak diberikan kembali dalam dosis uji melainkan diganti dengan Para amino-salicyclic Acid (PAS) dengan dosis 8 gram/hari. Sesuai pedoman apabila pasien mengalami efek samping gangguan kejiwaan karena sikloserin, maka sikloserin dapat diganti dengan PAS. ${ }^{1}$ Hingga saat ini efek samping psikosis tidak pernah ditemukan kembali pada pasien 3 .

\section{Lama pemberian paduan OAT}

Pasien 1 dan 2 telah menyelesaikan tahap awal paduan OAT dan memiliki konversi biakan dari positif menjadi negatif pada bulan ke 4 pengobatan. Total lama tahap awal kedua pasien tersebut adalah selama 8 bulan dan dilanjutkan dengan tahap lanjutan yaitu selama 14 bulan. Hal ini sesuai pedoman bahwa lama pengobatan tahap awal adalah 4 bulan setelah terjadi konversi biakan dan lama tahap lanjutan merupakan hasil pengurangan antara total lama pengobatan (22 bulan) dengan tahap awal ( 8 bulan). ${ }^{1}$ Sementara sampai saat ini pasien 3, 4, dan 6 masih dalam tahap awal pengobatan.

\section{Drop out dan penanganannya}

Sampai dengan laporan seri kasus ini dibuat, pasien ke-2 dan ke-5 telah mangkir (drop out) dari pengobatannya. Pasien 2 drop out dari pengobatan tahap lanjut TB pre XDR, sedangkan pasien 5 drop out pada bulan pertama (lama pengobatan $<4$ minggu) tahap awal pemberian paduan OAT. Telah dilakukan konseling intensif pada pasien dan keluarga mengenai kepatuhan berobat. Alasan sulitnya akses geografis dan ekonomi menjadi alasan kedua pasien ini tidak melanjutkan pengobatan. Pihak rumah sakit sudah bekerja sama melibatkan banyak pihak mulai dari dinas kesehatan kabupaten, puskesmas kecamatan, hingga tokoh agama setempat untuk mendatangi pasien, namun baik 
pasien dan keluarga tetap menolak untuk melanjutkan pengobatan.

\section{KESIMPULAN}

TB resistan obat merupakan fenomena buatan manusia (man-made disaster) yang saat ini bersifat emerging. Jumlah dan jenis obat yang banyak dan beragam, serta masa pengobatan yang lebih panjang merupakan kerumitan dalam penanganan kasus ini. Akan tetapi kerumitan ini bukan berarti menjadi hambatan bagi pelayanan kesehatan di daerah terpencil dengan fasilitas terbatas untuk menangani kasus TB resistan obat. Pedoman Manajemen Terpadu Pengendalian TB resistan obat sudah diterbitkan oleh Kementerian Kesehatan Indonesia. Guna menjamin terlaksananya program pemberantasan TB resistan obat yang sesuai dengan pedoman, maka diperlukan usaha, komitmen, serta kolaborasi yang baik dan berkesinambungan antara fasilitas pusat rujukan dengan fasilitas kesehatan di daerah sampai tingkat kabupaten. Namun hal terpenting dalam penanganan kasus TB resistan obat adalah pencegahan, salah satunya dengan pengobatan TB regular sampai tuntas.

\section{DAFTAR PUSTAKA}

1. Kementerian Kesehatan Republik Indonesia Direktorat Jenderal Pengendalian Penyakit dan Penyehatan Lingkungan. Pedoman Nasional Pengendalian Tuberkulosis 2014. Jakarta.

2. Kementerian Kesehatan Republik Indonesia Direktorat Jenderal Pengendalian Penyakit dan Penyehatan Lingkungan. Petunjuk Teknis Manajemen Terpadu Pengendalian Tuberkulosis Resistan Obat 2014. Jakarta.

3. Bhardwaj P, Deshkar AM, Verma R., Side Effects Encountered in Treatment of Multidrug-resistant Tuberculosis: A 3-Year Experience at First Dots Plus Site of Chhattisgarh. International Journal of Scientific Study. August 2015; 3 (5):104-7.
4. Lomtadze N, Aspindzelashvili R, Janjgava M, Mirtskhulava V, Wright A, Blumberg HM, et.al. Prevalence and Risk Factors for Multidrug Resistant Tuberculosis in Republic of Georgia: A Population Based Study. Int J Tuberc Lung Dis. January 2009; 13(1): 68-73.

5. He XC, Zhang XX, Zhao Jn, Liu Y, Yu CB, Yang GR, et al. Epidemiological Trends of Drug-Resistant Tuberculosis in China from 2007 to 2014. Medicine (Baltimore). April 2016; 95(15): e3336.

6. Bhatt G, Vyas S, Trivedil K. An Epidemiological Study of Multi Drug Resistant Tuberculosis.Indian J Tuberc. January 2012;59(1):18-27.

7. Gomes M, Correia A, Mendonça D, Duarte. Risk Factors for Drug Resistant Tuberculosis. Journal of Tuberculosis Research, 2014;(2); 111-18.

8. García S, Blanco AR, Pérez JLV, Viejo MAG, Hernández MJ J, López $\mathrm{O}$, et al. Risk factors for multidrug-resistant tuberculosis in a tuberculosis unit in Madrid, Spain. Eur J Clin Microbiol Infect Dis. April 2009;28(4): 325-30

9. Da Silva PEA, Palomino JC. Molecular basis and mechanisms of drug resistance in Mycobacterium tuberculosis: classical and new drugs. Journal of Antimicrobial Chemoteraphy. May 2011;66(7); 1417-30.

10. Suchindran S, Brouwer ES, Van Rie A. Is HIV Infection a Risk Factor for Multi-Drug Resistant Tuberculosis? A Systematic Review. PLoS ONE. May 2009; 4(5): e556.

11. World Health Organization. Companion Handbook to the WHO guidelines for the programmatic management of drug-resistant tuberculosis. Geneva, Switzerland: WHO; 2014, 1-446.

12. Archibald C. Cohen. Pyridoxine in the Prevention and Treatment of Convulsions and Neurotoxicity due to Cycloserine. Ann N Y Acad Sci. 1969 Sep 30;166(1): 346-9.

13. Singhal P, Dixit P, Singh P, Jaiswal I, Singh M, Jain A. A study on pre-XDR \& XDR tuberculosis \& their prevalent genotypes in clinica isolates of Mycobacterium tuberculosis in north India. Indian J Med Res. 2016 Mar;143(3): 341-7.

14. Zaki SA. Adverse Drug Reaction and Casualty Assessment Scale. Lung India. June 2011;28(2): 152-3.

15. Wood JD, Peesker SJ, Gorecki DK, Tsui D. Effect ofl-Cycloserine on brain GABA metabolism. Can J Physiol Pharmacol. February 1978; 56(1): 62-8.

16. Rouaud E, Billard JM. D-Cycloserine facilitates synaptic plasticity but impairs glutamatergic neurotransmission in rat hippocampal slices. Br J Pharmacalol. November 2003; 140(6): 1051-6.

17. Jacobs TQ, Ross A. Adverse effects profile of multidrug-resistant tuberculosis treatment in a South African outpatient clinic. S Afr Farm Pract. 2012;54(6): 531-9. 